\title{
Heat transfer rates in hot shell, cold tube inclined baffled small shell, and tube heat exchanger using CFD and experimental approach
}

\author{
Devanand D. Chillal*, Uday C. Kapale**, N.R. Banapurmath*** and T. M. Yunus Khan**** \\ * Department of Automobile, Engineering, Basaveshwar Engineering College (Autonomous), Bagalkot, Karnataka, India \\ ** Department of Mechanical Engineering, Sanjay Ghodawat University, Kolhapur, Maharashtra, India \\ *** School of Mechanical Engineering, B.V.B. College of Engineering and Technology, KLE Technological University, Hubballi, \\ Karnataka, India \\ ****Department of Mechanical Engineering, College of Engineering, King Khalid University, Abha, 61421, Saudi Arabia.
}

$\begin{array}{ll}\text { Submitted } & : 03 / 08 / 2019 \\ \text { Revised } & : 30 / 11 / 2020 \\ \text { Accepted } & : 08 / 12 / 2020\end{array}$

\begin{abstract}
The work presented is an effort to realize the changes occurring for convective coefficients of heat transfer in STHX fitted with inclined baffles. Effort has been undertaken using Fluent, a commercially available CFD code on a CAD model of small STHX with inclined baffles with cold liquid flowing into the tubes and hot liquid flowing in the shell. Four sets of CFD analysis have been carried out. The hot liquid flow rate through shell compartments varied from $0.2 \mathrm{~kg} / \mathrm{sec}$ to $0.8 \mathrm{~kg} / \mathrm{sec}$ in steps of $0.2 \mathrm{~kg} / \mathrm{sec}$, while keeping the cold liquid flow condition in tube at $0.4 \mathrm{~kg} / \mathrm{sec}$ constant. Heat transfer rates, compartment temperatures, and overall heat transfer coefficients, for cold liquid and hot liquid, were studied. The results given by the software using CFD approach were appreciable and comparatively in agreement with the results available by the experimental work, which was undertaken for the same set of inlet pressure conditions, liquid flow rates, and inlet temperatures of liquid for both hot and cold liquids. The experimental output results were also used to validate the results given by the CFD software. The results from the CFD analysis were further used to conclude the effect of baffle inclination on heat duty. The process thus followed also helped realize the effects of baffle inclination on convective heat transfer coefficient of the liquid flow through the shell in an inclined baffle shell and tube heat exchanger. The temperature plots for both cold and hot liquid were also generated for understanding the compartmental temperature distributions inclusive of the inlet and outlet compartments. The heat duty for a heat exchanger has been found to increase with the increase in baffle inclinations from zero degree to 20 degrees. Likewise, the convective heat transfer coefficients have also been found to increase with the increase in baffle inclinations.
\end{abstract}

Keywords: STHX-Shell and tube heat exchanger; CFD-Computational fluid dynamics. 


\section{NOMENCLATURE}

\begin{tabular}{|c|c|c|}
\hline Symbol & Specification & Dimension \\
\hline do & Outer diameter of tube & $0.015875 \mathrm{~m}$ \\
\hline $\mathrm{di}$ & Inner diameter of tube & $0.01448 \mathrm{~m}$ \\
\hline ro & Outer radius of tube & $0.0079 \mathrm{~m}$ \\
\hline $\mathrm{ri}$ & Inner radius of tube & $0.00724 \mathrm{~m}$ \\
\hline $\mathrm{PT}$ & Tube pitch & $0.02 \mathrm{~m}$ \\
\hline $\mathrm{Lo}$ & Total length of shell with tube end sheets & $0.64 \mathrm{~m}$ \\
\hline $\mathrm{L}$ & Length of Flow & $0.604 \mathrm{~m}$ \\
\hline $\mathrm{Bt}$ & Baffle thickness & $0.0015 \mathrm{~m}$ \\
\hline $\mathrm{Bs}$ & Baffle spacing & $0.086 \mathrm{~m}$ \\
\hline $\mathrm{Ds}$ & Inner diameter of shell & $0.076 \mathrm{~m}$ \\
\hline $\mathrm{Nb}$ & Number of Baffles & 06 \\
\hline $\mathrm{N}$ & Number of Tubes & 08 \\
\hline $\mathrm{Nc}$ & Number of tube passes & 01 \\
\hline $\mathrm{Np}$ & Number tube rows cross during shell flow & 03 \\
\hline
\end{tabular}

\section{INTRODUCTION}

Fossil fuel has been the main source of energy for automotive traction and is widely used in the road transportation (Rojey and Alexandre, 2009). This is true both for light and heavy commercial goods transport at all levels. Automotive uses fossil fuel to run the internal combustion engine to generate power and continue to use them in near future. The exhaust from the automotive contains heat and is wasted, which also results in the addition of pollutants to air. If this exhaust waste is recovered by using a suitably modified heat exchanger (Bari and Hossain., 2013), this recovered heat may be used for producing electricity with thermoelectric generators or to preheat in turbocharging principle (Copeland, Pesiridis, Martinez-Botas, Rajoo, Romagnoli \& Mamat, 2014). This may improve the performance of the automotive worldwide. It may also alleviate the pollution problem to some extent. Hence, with this priority, the present work is envisaged on the development of an inclined baffle heat exchanger, as possible heat recovery equipment. STHX are easy to construct and effective heat transfer equipment. These are convenient to use and find their usage in various areas like industry, agriculture, automotive, and so on. These may be available in various sizes and configurations with change in number of tubes, tube bundles, baffle shapes, flow patterns, flow liquid, and so on (Kakac S, 1981). They are simple and easy to clean and assemble. The STHX have been considered for better heat transfer coefficients but have large shell side liquid pressure drops (Kern D Q, 1950). Thus, if it is possible to have a modified STHX, which has improved heat transfer coefficient and reduced pressure drop (Chillal and Kapale, 2018), then it may serve as equipment in automotive exhaust heat recovery. With this perspective, a 
work is proposed to understand the effects of baffle inclinations on heat transfer rate variation. Gay et al. (1977) conducted experimental works on segmental baffle STHX and showed that the heat transfer coefficients for shell side decreased with the increase in baffle cut. Li et al. (1998) studied the effect of baffle spacing on shell side heat transfer rate in a segmental baffle STHX and found that the increase in baffle spacing led to an increase in the compartmental heat transfer rate due to increased fluid velocity through tube bundles. Clarke et al. (2000) studied the effect of fouling in a segmental baffle STHX using CFD technique. For this purpose, a commercial CFD code "FLUENT" was used. The study helped identify the potential regions of intense fouling in baffle compartments. Stevanovic et al. (2001) evaluated fouling in shell compartments of segmental baffle STHX using CFD technique. The author concluded the potential of the CFD technique used to study the heat transfer equipment. Son et al. (2001) undertook work to study the effects on shell side fluid flow with spiral baffles. CFX, a commercially available CFD code, was used. The work stated that heat transfer rates on shell side were better with spiral baffles as compared to segmental baffles. Zhang et al. (2009) studied the effect of overlapped helically shaped baffles on heat duty in STHX with continuous and discontinuous types of baffles. A CFD technique was adopted using 'Fluent', a commercially available CFD code, and it was found that the discontinuous type of helical baffles gave lesser heat transfer coefficients compared with continuous type of helical baffles. Ozden et al. (2010) studied the effect of baffle cut and baffle spacing on the heat duty on shell side using CFD approach. The study showed that the increase in number of baffles through tube packs improved the shell side heat transfer coefficients.

From the exhaustive literature survey carried out on STHX, it was found that not much work has been carried out on the design and development of STHX with inclined baffles. Further, the influence of inclined baffles on shell side heat transfer coefficients, heat duty for STHX with incline baffles as compared with segmental baffles, pressure drops of shell side fluid flow, and compartmental fluid flow patterns on shell side were not investigated in detail. Accordingly, the objectives of the present work involve the use of inclined baffle STHX with $10^{\circ}$ and $20^{\circ}$ baffle inclinations and evaluating the heat duty using CFD approach for a defined set of tube and shell fluid flow conditions. Further determination of heat duty for 0-degree segmental baffle STHX using CFD approach is done compared with the heat duties of 10-degree and 20-degree STHX considering the same set of shell/tube side fluid flow conditions. The study would help realize the influence of baffle inclination on heat duty for STHX. For this STHX, working models with $0^{\circ}, 10^{\circ}$, and $20^{\circ}$ inclined baffles were fabricated, and exhaustive experimental works were undertaken. Finally, experimental results were used to validate the results from CFD approach.

\section{EXPERIMENTAL METHODOLOGY}

A STHX with $750 \mathrm{~mm}$ length that may be accommodated in exhaust manifold was considered, and analysis was carried out both experimentally and using CFD approach. Two baffle inclinations of ten degree and twenty degrees were developed. Eight copper tubes were used to form tube bundle with a $45^{0}$ triangular pitch. Six baffles were located with equal spacing with inclination mentioned along the shell flow direction. The material and properties used for the STHX with specifications are available in Appendix. The shell and the baffle plates were made up of steel. A hot shell-cold tube liquid flow condition was used in experimental and CFD analysis. Water was used as tube side cold liquid with constant flow rate of $0.4 \mathrm{~kg} / \mathrm{sec}$. Four liquid flow conditions were considered on shell with hot water of $0.2 \mathrm{~kg} / \mathrm{sec}, 0.4 \mathrm{~kg} / \mathrm{sec}, 0.6 \mathrm{~kg} / \mathrm{sec}$, and $0.8 \mathrm{~kg} / \mathrm{sec}$. The experimental setup was developed as described, and the study was conducted initially for the flow conditions mentioned. Later, the same input liquid flow conditions were used for CFD analysis. Sufficient time was allowed for the flow conditions to reach the steady state to have better approximate values of temperature, pressure, and discharge. The output parameters were tabulated, which were temperature and pressure. The same conditions as mentioned for experimental setup were used as inputs for the CFD analysis using 'Fluent', a commercially available CFD code. The outputs from the two approaches were compared. The reader is suggested to understand the meaning of inclined baffle going through figure 1 . To assemble the tube bundle through baffle hole and alignment of baffle plates into the shell, sufficient care is taken during fabrication. The baffles were drilled with holes using plates in inclined position through the drilling spindle axis to ensure proper 
positioning of the tube bundle through the baffle holes. The peripheral edge of the baffle plate was also generated by cutting the baffles in the inclined position of the plate to ensure proper mating of baffle edge with the shell inner circular surface.

Figure 1 shows the definition of baffle inclination. The baffle is inclined towards the shell side fluid flow direction by specified angle to define baffle inclination.

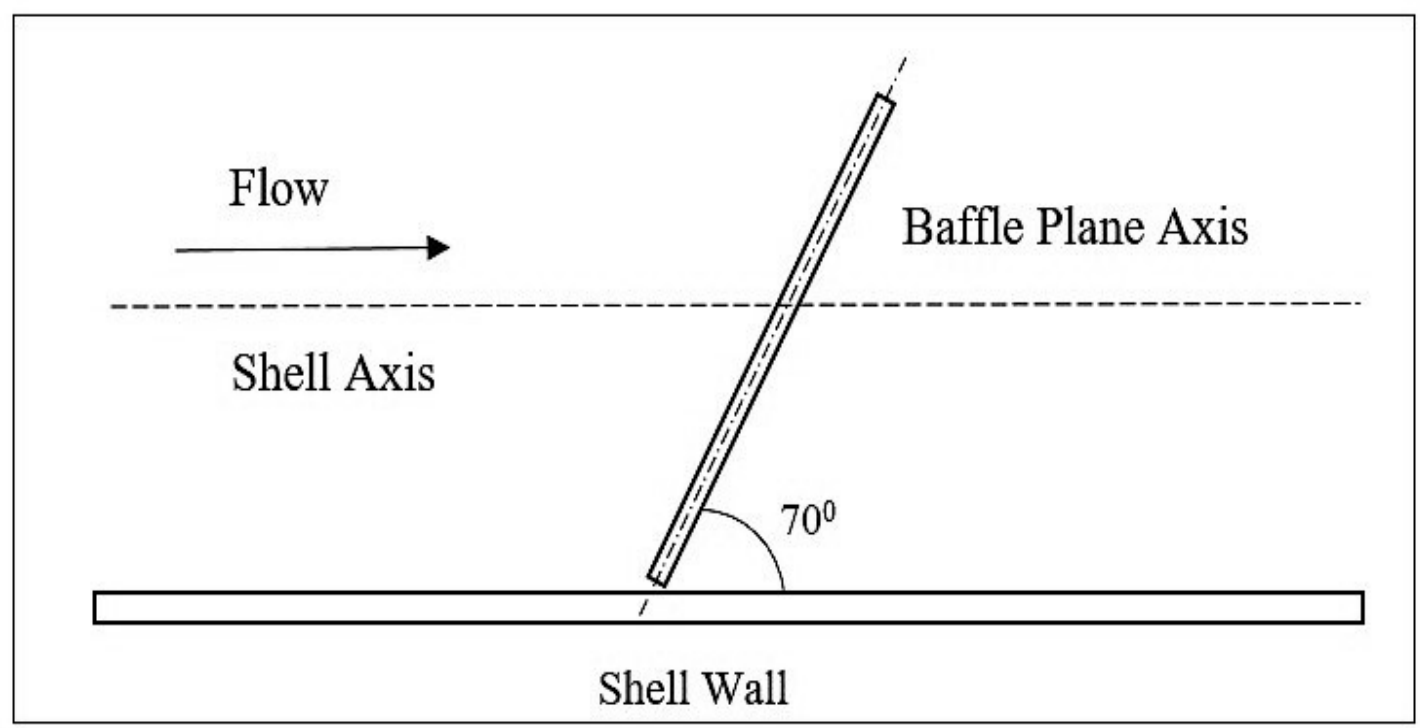

Figure 1. Representation for baffle angle.

Figure 2 shows the experimental setup used for Hot Shell Cold Tube Inclined Baffle STHX. The locations of fluid lines with temperature, pressure, and flow measuring instruments are clearly shown for both shell and tube side fluid flow.

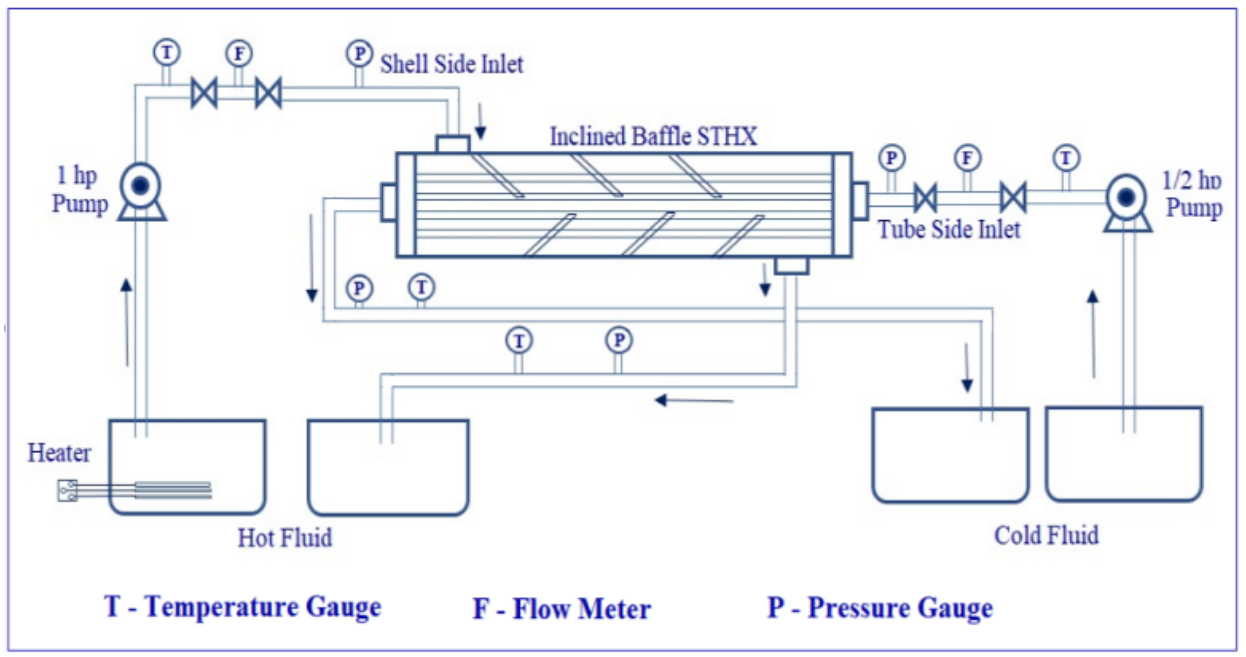

Figure 2. Experimental Setup for Hot Shell Cold Tube Inclined Baffle STHX. 


\section{CFD METHODOLOGY}

The inlet flow rates and temperatures mentioned in experimentation were used for hot shell and cold tube inclined baffle heat exchanger solution by CFD approach using 'Fluent', a commercially available code. The number of iterations varied till the convergence conditions were achieved. The heat transfer rates for shell liquid and tube liquid were found to be equal for convergence. The material and both hot-cold liquid properties used for CFD analysis using 'Fluent' are given in Appendix. The material properties were taken from the data records, and the average fluid properties used for CFD analysis were found from the water properties tables for the appropriate temperatures used in experimental approach. The shell, tube end sheets, nozzles, and end covers were made up of carbon steel while, baffle plates with steel. The tubes were made up of copper. The results for $10^{\circ}$ and $20^{\circ}$ inclined baffle heat exchangers from numerical and experimental approach were compared for validation of CFD results. The results given by $\mathrm{CFD} /$ numerical approach validation are shown in graphs from figures 3 to 5 and tables 3 and 4, respectively. The results reasonably agree for temperature outputs in Kelvin found from numerical and experimental approach, and the variation is found to be less than $0.5 \%$ as seen from table 3 . Table 1 shows the details of the boundary conditions used in the CFD analysis by 'Fluent' software. The boundary conditions applied for both tube side fluid and shell side fluid and initial conditions defined are shown. The specifications of STHX used for both CAD modeling and fabrication of experimental models are detailed in nomenclature.

Table 1. Boundary Conditions Used in Conjugate Solution Using 'Fluent'.

\begin{tabular}{|c|c|c|}
\hline \multicolumn{3}{|c|}{ Boundary Conditions } \\
\hline Shell side & Tube Side & Initial conditions \\
\hline Shell side Hot inlet & Tube side Cold inlet & Temperature \\
\hline Temperature input & Temperature input & Hot fluid temperature \\
\hline Mass velocity input & Mass velocity input & Cold fluid temperature \\
\hline & Tube side Cold outlet & Steel temperature \\
\hline Shell side Hot outlet & Temperature input & Tube wall \\
\hline Temperature output & Mass velocity input & Temperature $=$ L-conjugate \\
\hline Pressure output & & $\begin{array}{l}\text { Outer Shell wall Heat flux } \\
=0\end{array}$ \\
\hline
\end{tabular}

The material and their properties used in CFD work were the same, using which the experimental models were fabricated.

\section{RESULTS AND DISCUSSION}

It is mentioned in the experimental and CFD approach that two baffle angles of 10 and 20 degrees were used to evaluate temperatures output on shell and tube side liquid and heat duty of the heat exchanger. The tables 2,3 , and 4 below (page nos. 11 and 12) show the experimental results for the cases mentioned and their comparison with numerical/CFD approach for the same input temperatures and flow conditions. The experimental and numerical results thus found showed close agreement in temperature for both shell and tube side liquid and heat transfer outputs for the heat exchanger. Thus, numerical results were validated. Further, the results found by numerical approach for $0^{0}, 10^{\circ}$, and $20^{\circ}$ inclined baffle STHX for temperature and heat duty outputs are compared through graphs and used for stating concluding remarks. The temperatures were noted for shell and tube fluid at inlet and exit ports during 
experimentation. The temperatures were observed for four sets of constant shell side fluid flow rates $(0.2,0.4,0.6$, and $0.8 \mathrm{~kg} / \mathrm{sec}$ ). The tube side cold fluid flow rate was kept constant at $0.4 \mathrm{~kg} / \mathrm{sec}$.

In table 3, the results for 10-degree inclined baffle STHX by CFD method are shown. These results are compared with experimental results for validation of numerical results.

In table 4, the results for 20-degree inclined baffle STHX by CFD method are shown. These results are compared with experimental results for validation of numerical results.

Figures 3, 4, and 5 show the temperature contours for different baffle inclinations with tube side constant flow rate of $0.4 \mathrm{~kg} / \mathrm{sec}$ and varied shell side constant flow rates ranging from $0.2,0.4,0.6$, and $0.8 \mathrm{~kg} / \mathrm{sec}$, respectively. Figure 3 shows the temperature contours for shell side fluid with 0-degree segmental baffles STHX for shell side flow rate of $0.6 \mathrm{~kg} / \mathrm{sec}$. These are plotted by the CFD software after satisfying convergence condition.

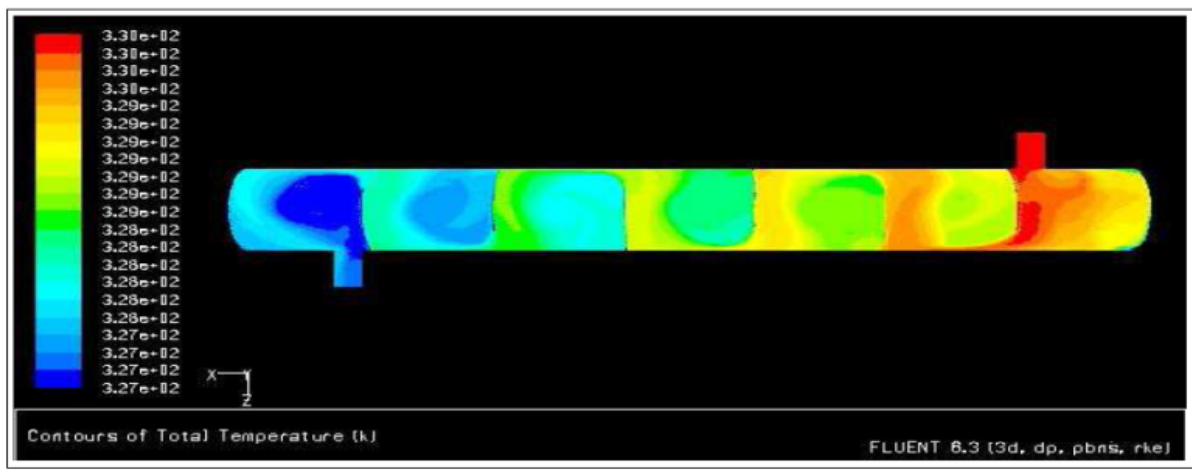

Figure 3. Temperature contours for 00 baffle for tube side constant flow rate of $0.4 \mathrm{~kg} / \mathrm{sec}$ and shell side constant flow rate of $0.6 \mathrm{~kg} / \mathrm{sec}$.

Figure 4 shows the temperature contours for shell side fluid with 10-degree inclined baffles STHX for shell side flow rate of $0.6 \mathrm{~kg} / \mathrm{sec}$. These are plotted by the CFD software after satisfying convergence condition.

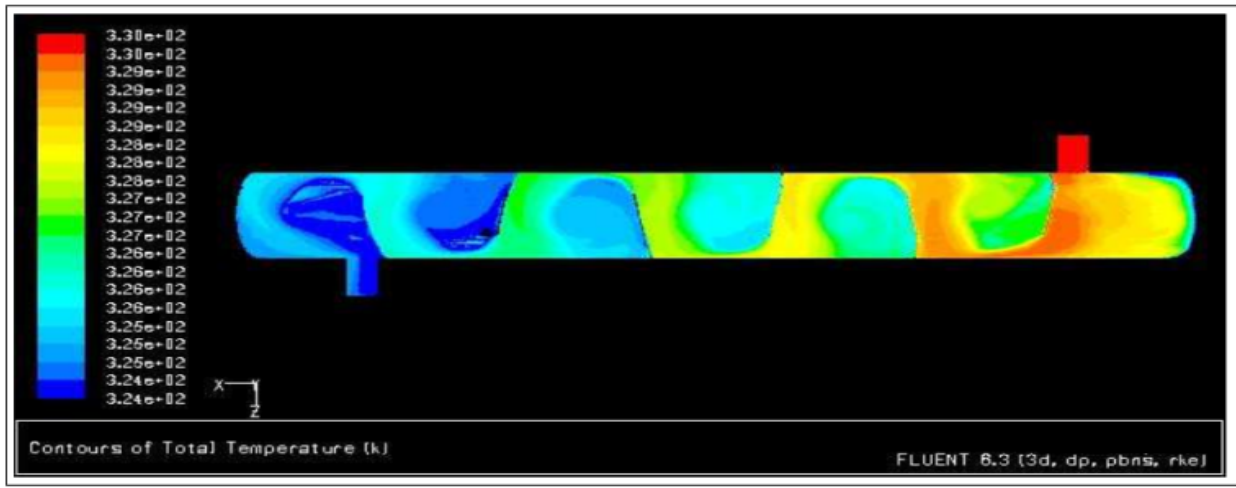

Figure 4. Temperature contours for $10^{\circ}$ baffles for tube side constant flow rate of $0.4 \mathrm{~kg} / \mathrm{sec}$ and shell side constant flow rate of $0.2 \mathrm{~kg} / \mathrm{sec}$. 
Figure 5 shows the temperature contours for shell side fluid with 20-degree inclined baffles STHX for shell side flow rate of $0.6 \mathrm{~kg} / \mathrm{sec}$. These are plotted by the CFD software after satisfying convergence condition.

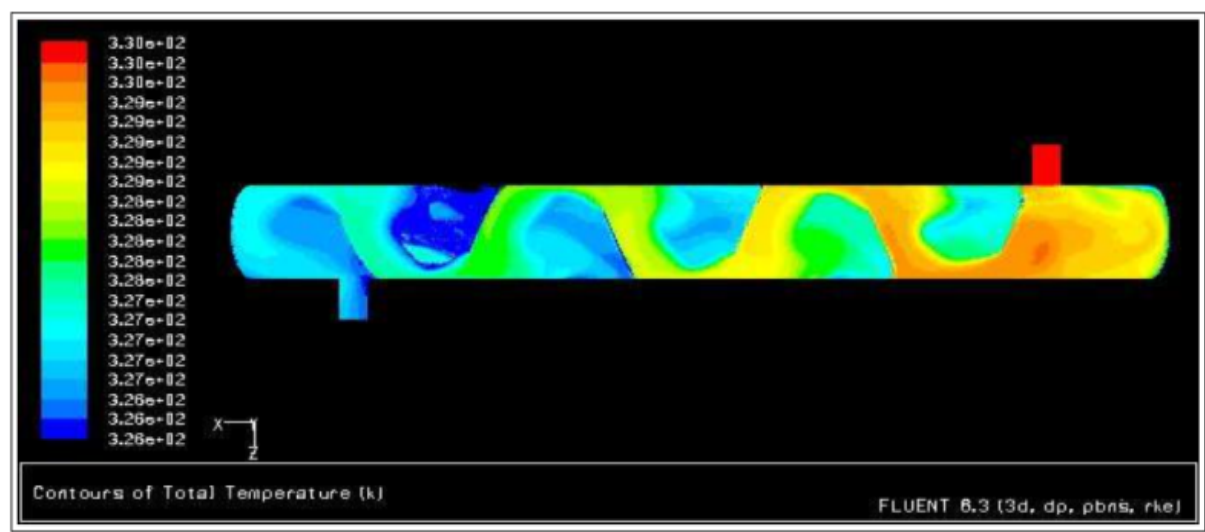

Figure 5. Temperature contours for $20^{\circ}$ baffles for tube side constant flow rate of $0.4 \mathrm{~kg} / \mathrm{sec}$ and shell side constant flow rate of $0.4 \mathrm{~kg} / \mathrm{sec}$.

Table 2. Experimental results for $10^{\circ}$ and $20^{\circ}$ inclined baffle STHX.

\begin{tabular}{|c|c|c|c|c|c|c|c|c|}
\hline $\begin{array}{c}\text { Shell } \\
\text { flow } \\
\text { in kg/sec }\end{array}$ & \multicolumn{4}{|c|}{$\begin{array}{c}\text { Temperature in K for 10 } \\
\text { baffle STHX }\end{array}$} & \multicolumn{3}{|c|}{$\begin{array}{c}\text { inclined } \\
\text { bemperature in K for 20 } \\
\text { ba- inclined }\end{array}$} \\
\hline & $\begin{array}{c}\text { Tube } \\
\text { in }\end{array}$ & Tube out & Shell in & $\begin{array}{c}\text { Shell } \\
\text { ant }\end{array}$ & Tube in & $\begin{array}{c}\text { Tube } \\
\text { out }\end{array}$ & Shell in & $\begin{array}{c}\text { Shell } \\
\text { out }\end{array}$ \\
\hline 0.2 & 301.1 & 304.4 & 330.3 & 323.5 & 301.0 & 304.3 & 330.0 & 324.1 \\
\hline 0.4 & 301.0 & 305.4 & 330.0 & 325.7 & 301.1 & 305.5 & 330.1 & 326.0 \\
\hline 0.6 & 301.1 & 306.2 & 330.0 & 326.8 & 301.1 & 306.6 & 329.9 & 326.8 \\
\hline 0.8 & 301.1 & 307.1 & 330.1 & 327.3 & 301.0 & 307.3 & 329.9 & 328.1 \\
\hline
\end{tabular}

Table 3. Comparison of experimental and CFD results for $10^{\circ}$ inclined baffle STHX.

\begin{tabular}{|c|c|c|c|c|c|c|}
\hline \multirow{3}{*}{$\begin{array}{l}\text { Shell } \\
\text { side } \\
\text { Flow } \\
\text { rate } \\
\text { in } \\
\mathrm{kg} / \mathrm{sec}\end{array}$} & \multicolumn{4}{|c|}{ Temperature in $\mathbf{K}$} & \multicolumn{2}{|c|}{ Heat Duty } \\
\hline & \multicolumn{2}{|c|}{ Shell outlet } & \multicolumn{2}{|c|}{ Tube outlet } & \multirow{2}{*}{$\begin{array}{c}\text { Numeri } \\
\text { cal }\end{array}$} & \multirow{2}{*}{$\begin{array}{c}\text { Experi } \\
\text { ment }\end{array}$} \\
\hline & Numerical & Experiment & Numerical & Experiment & & \\
\hline 0.2 & 324.52 & 323.5 & 303.64 & 304.4 & 4586 & 5605 \\
\hline 0.4 & 326.5 & 325.7 & 304.4 & 305.4 & 5875 & 6598 \\
\hline 0.6 & 327.4 & 326.8 & 304.8 & 306.2 & 6610 & 7408.5 \\
\hline 0.8 & 328.1 & 327.3 & 305.5 & 307.1 & 7170 & 7736.4 \\
\hline
\end{tabular}


Table 4. Comparison of experimental and CFD results for $20^{\circ}$ inclined baffle STHX.

\begin{tabular}{|c|c|c|c|c|c|c|}
\hline \multirow{3}{*}{$\begin{array}{l}\text { Shell side } \\
\text { Flow rate } \\
\text { in } \mathrm{kg} / \mathrm{sec}\end{array}$} & \multicolumn{4}{|c|}{ Temperature in ${ }^{0} \mathrm{~K}$} & \multicolumn{2}{|c|}{ Heat Duty } \\
\hline & \multicolumn{2}{|c|}{ Shell outlet } & \multicolumn{2}{|c|}{ Tube outlet } & \multirow{2}{*}{$\begin{array}{c}\text { Numeric } \\
\text { al }\end{array}$} & \multirow{2}{*}{$\begin{array}{c}\text { Experime } \\
\mathrm{nt}\end{array}$} \\
\hline & Numerical & Experiment & Numerical & Experiment & & \\
\hline 0.2 & 324.6 & 324.1 & 303.6 & 304.3 & 4533 & 5651.8 \\
\hline 0.4 & 326.6 & 326.0 & 304.3 & 305.5 & 5739 & 6638.3 \\
\hline 0.6 & 327.4 & 326.8 & 304.8 & 306.6 & 6608 & 7309.6 \\
\hline 0.8 & 328.0 & 328.1 & 305.4 & 307.3 & 7741 & 7804.6 \\
\hline
\end{tabular}

Figure 6 and 7 show the shell side fluid exit temperature for all four sets of shell fluid flow rates for STHX with 100 baffle inclination. These are plotted for the temperature outputs obtained from experimental and numerical approach. Figures 8 to 9 show the shell side fluid exit temperature for all four sets of shell fluid flow rates for STHX with $20^{\circ}$ baffle inclination.

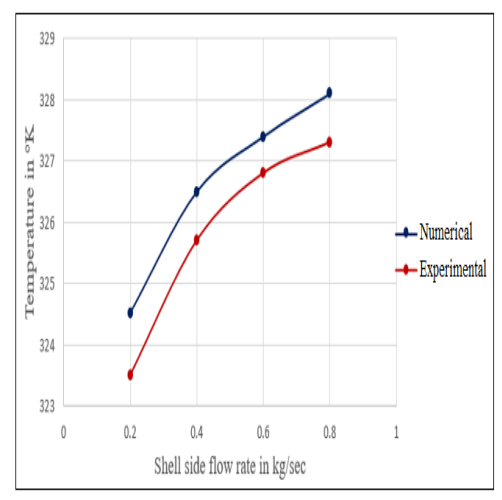

Figure 6. Shell exit temperature for $10^{\circ}$ baffles STHX.

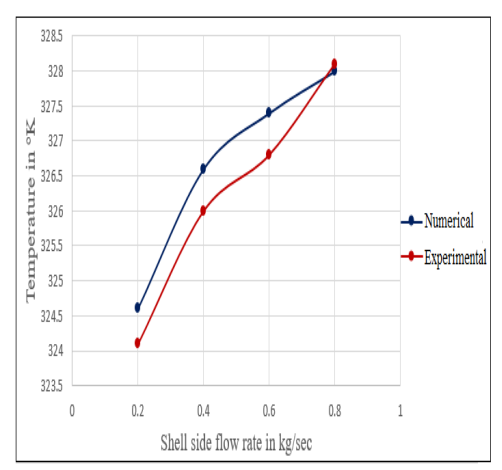

Figure 8. Shell exit temperature for $20^{\circ}$ baffles STHX.

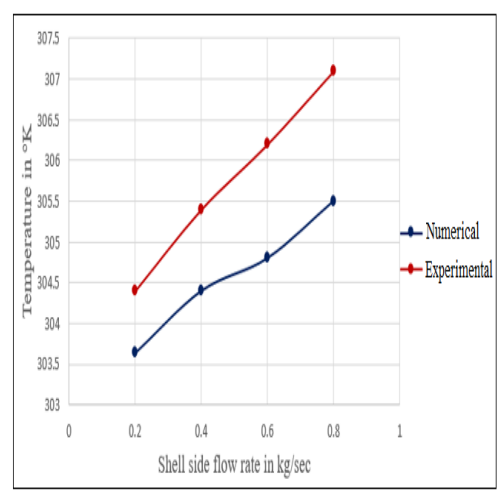

Figure 7. Tube exit temperature for $10^{\circ}$ baffles STHX.

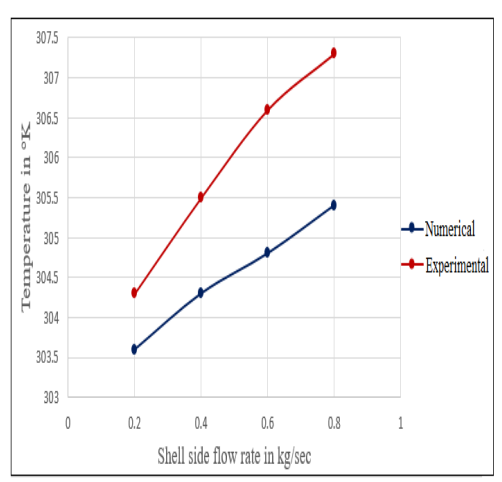

Figure 9. Tube exit temperature for $20^{\circ}$ baffles STHX. 
Figures 10 and 11 show heat duty and heat transfer coefficients, respectively, for all three baffle sets. The values for heat duty and heat transfer coefficients obtained by CFD are compared for all three baffle sets. The results from numerical analysis for three sets of baffles are plotted for heat transfer rates and overall heat transfer coefficients for heat exchanger against the varying shell side flow rates.

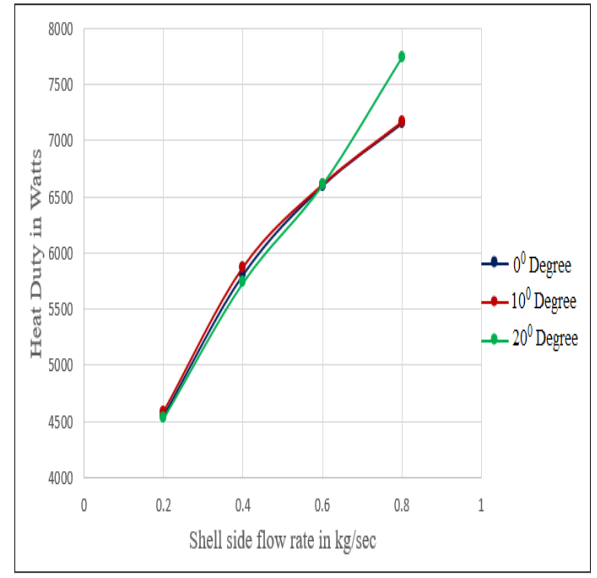

Figure 10. Heat duty for $0^{\circ}, 10^{\circ}$, and $20^{\circ}$ baffles STHX.

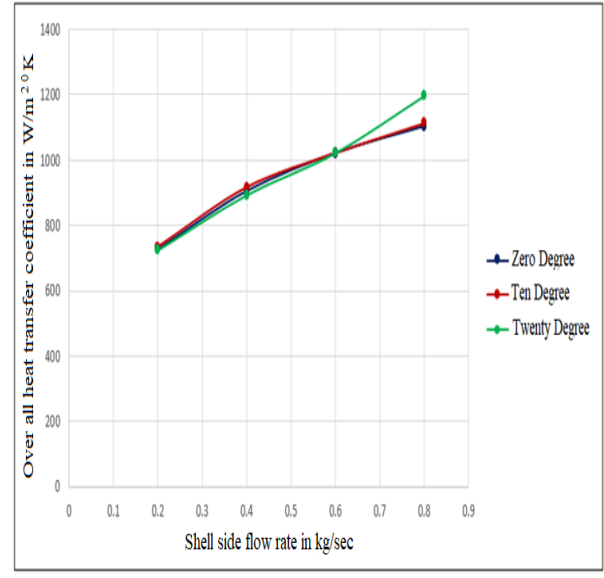

Figure 11. Heat Transfer Coefficients for $0^{\circ}, 10^{\circ}$, and $20^{\circ}$ baffle STHX.

Figures 12 and 13 show heat duty and heat transfer coefficients, respectively, for all three baffle sets in bar graph. The values for heat duty and heat transfer coefficients obtained by CFD are compared for all three baffle sets.

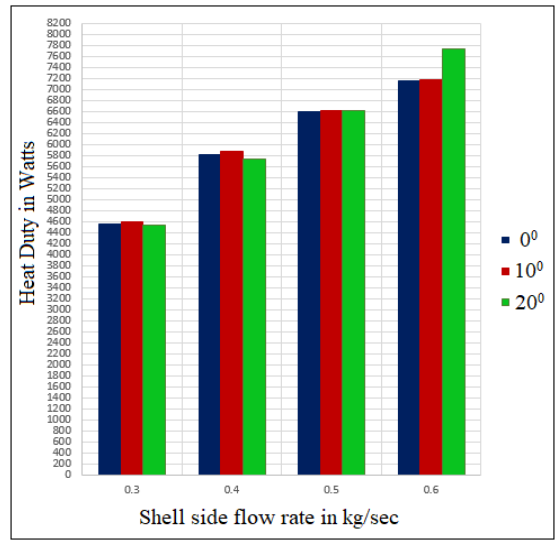

Figure 12. Heat duty for $0^{0}, 10^{\circ}$, and $20^{\circ}$ baffles STHX.

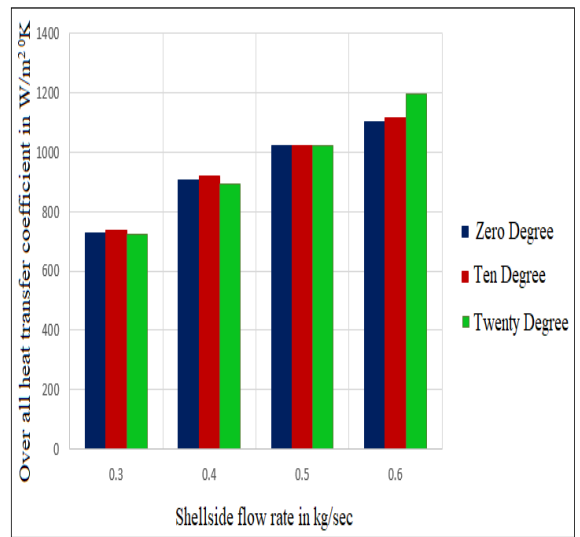

Figure 13. Heat Transfer Coefficients for $0^{\circ}$, $10^{\circ}$, and $20^{\circ}$ baffles STHX. 


\section{FOR $10^{0}$ INCLINED BAFFLE STHX}

The water outlet temperature for shell side increases with the increase in water flow rate from 0.2 to $0.8 \mathrm{~kg} / \mathrm{sec}$ and water outlet temperature in degree Celsius for numerical and experimental values match closely with up to $2 \%$ variation as seen in figure 6 . The water outlet temperature on tube side flow increases with the increase in shell side water flow rate from 0.2 to $0.8 \mathrm{~kg} / \mathrm{sec}$ and constant tube flow rate of $0.4 \mathrm{~kg} / \mathrm{sec}$. The tube outlet temperatures in degree Celsius for numerical and experimental values match closely with up to maximum $5 \%$ variations as seen in figure 7 . The heat duty increases with the increase in shell side flow rate from 0.2 to $0.8 \mathrm{~kg} / \mathrm{sec}$, and the heat duty for experimental and numerical values is found to vary with maximum of $22 \%$ for lowest shell side liquid flow rate to minimum of $8 \%$ for highest shell side liquid fluid flow rate as seen in figures 10 and 12 .

\section{FOR $20^{\circ}$ INCLINED BAFFLE STHX}

The water outlet temperature for shell side increases with the increase in water flow rate from 0.2 to $0.8 \mathrm{~kg} / \mathrm{sec}$ and water outlet temperature in degree Celsius for numerical and experimental values match closely with up to $1 \%$ variation as seen in figure 8 . The water outlet temperature on tube side flow increases with the increase in shell side water flow rate from 0.2 to $0.8 \mathrm{~kg} / \mathrm{sec}$ and constant tube flow rate of $0.4 \mathrm{~kg} / \mathrm{sec}$. The tube outlet temperatures in degree Celsius for numerical and experimental values match closely with up to maximum $5.5 \%$ variations as seen in figure 9.

The heat duty increases with the increase in shell side flow rate from 0.2 to $0.8 \mathrm{~kg} / \mathrm{sec}$, and the heat duty for experimental and numerical values is found to vary with maximum of $24 \%$ for lowest shell side liquid flow rate to minimum of $8 \%$ for highest shell side liquid fluid flowrate as seen in figures 10 and 12 . The heat transfer coefficients were also found to be higher for heat exchanger with 20 degrees inclined baffle by $9 \%$ maximum when compared to zero degree segmental baffle heat exchanger.

\section{CONCLUSION}

STHX with $20^{\circ}$ inclined baffle exhibits higher heat duty for higher shell side fluid flow rates. The heat duty has been enhanced by about $8 \%$ for STHX with $20^{\circ}$ inclined baffles when compared with $0^{\circ}$ segmental baffles STHX as seen from figures 10 and 12 . The heat transfer coefficient is found to be highest for $20^{\circ}$ inclined baffles STHX and is found to be for higher shell side water flow rates. The heat transfer coefficient for $20^{\circ}$ inclined baffle STHX is about $9 \%$ higher when compared to 00 segmental baffle STHX as seen from figures 11 and 13 . Also, the coefficient of heat transfer for ten-degree baffle heat exchanger is higher by about $1 \%$ to $1.5 \%$ for when compared to zero-degree baffles at lower shell side fluid flow rates.

\section{ACKNOWLEDGMENT}

The authors extend their appreciation to the Deanship of Scientific Research at King Khalid University for funding this work through Grant Number R.G.P. 2/74/41. 


\section{REFERENCES}

Bari, Saiful and Shekh N. Hossain. 2013. Waste heat recovery from a diesel engine using shell and tube heat exchanger. Applied Thermal Engineering, 61.2: 355-363.

Chillal, D.D. and Kapale, U.C.2018. Study the effect of inclined baffles on heat duty for a small shell and tube heat exchanger with hot tube side fluid flow using CFD approach. International Journal of Mechanical and Production Engineering Research and Development (IJMPERD), Vol. 8, Issue 2: 1331-1338.

Chillal, D.D. and Kapale, U.C.2018. Study the effect of inclined baffles on shell side liquid flow pressure variation for a small shell and tube heat exchanger with hot tube side fluid flow using CFD approach. International Journal of Mechanical and Production Engineering Research and Development (IJMPERD) Vol. 8, Issue 2: 1313-1320.

Clarke, R. H., \& Nicolas, F.2000. CFD investigation of maldistribution effects on crude oil fouling in shell and tube exchangers. In Second International Conference on Petroleum and Gas Phase Behavior and Fouling, Copenhagen, Denmark.

Copeland, C., Pesiridis, A., Martinez-Botas, R., Rajoo, S., Romagnoli, A., \&Mamat, A.2014 Automotive Exhaust Waste Heat Recovery Technologies.

Emerson, W. H.1963. Shell-side pressure drop and heat transfer with turbulent flow in segmentally baffled shelland-tube heat exchangers. International Journal of Heat and Mass Transfer, 6(8): 649-668.

Gaddis, E. S., \&Gnielinski, V.1997. Pressure drop on the shell side of shell-and-tube heat exchangers with segmental baffles. Chemical Engineering and Processing: Process Intensification, 36(2): 149-159.

Gay, B., Mackley, N.V. and Jenkins, J.D.1981. Shell-side heat transfer coefficients in cylindrical heat exchangers the influence of geometrical factors. II—the leakage case. Letters in Heat and Mass Transfer, 8(6) :437-452.

Heidemann, W., Mohammadi, K., \& Mueller-Steinhagen, H.2006. Numerical investigation of the effect of baffle orientation and baffle cut on heat transfer and pressure drop of a shell and tube heat exchanger. International Heat Transfer Conference 13. Begel House Inc.

Jenkins, J. D., Gay, B., \&Nibber, S. P. S.1991. Shell side heat transfer coefficients in cylindrical heat exchangers. Variation along the exchanger length, I-The no-leakage case: Experimental. International communications in heat and mass transfer, 18(1): 1-10.

Kakac S.1981. Heat exchangers: thermal-hydraulic fundamentals and design. Misc-Sci/Eng.

Kapale, U. C.., and Chand, S.2006. Modeling for shell-side pressure drop for liquid flow in shell-and-tube heat exchanger. International Journal of Heat and Mass Transfer, 49(3): 601-610.

Kapale, U. C., Chand, S., Taamneh, Y., Ripperger, S., Lal, S., Kushari, A., \&Vasudevan, R. 2010.Modeling of single phase shell-side fluid heat transfer coefficient in shell-and-tube heat exchanger. International Journal of Dynamics of Fluids (IJDF), 6(1).

Kern D. Q.1950. Process heat transfer. Tata McGraw-Hill Education.

Lei, Y. G., He, Y. L., Li, R., \&Gao, Y. F.2008. Effects of baffle inclination angle on flow and heat transfer of a heat exchanger with helical baffles. Chemical Engineering and Processing: Process Intensification, 47(12): .2336-2345.

Li, H. D., and Kottke, V.1998. Visualization and determination of local heat transfer coefficients in shell-andtube heat exchangers for in-line tube arrangement by mass transfer measurements. Heat and mass transfer, 33(5-6): 371-376.

Ozden, E., \& Tari, I.2010. Shell side CFD analysis of a small shell-and-tube heat exchanger. Energy Conversion and Management, 51(5): 1004-1014.

Ozisik M. N.1985. Heat transfer: a basic approach.

Raj, K. T. R., \& Ganne, S.2012. Shell side numerical analysis of a shell and tube heat exchanger considering the effects of baffle inclination angle on fluid flow using CFD. Thermal Science, 16(4): 1165-1174.

Rojey, Alexandre.2009. Energy and Climate: How to achieve a successful energy transition. John Wiley \& Sons. 
Son, Y. S., \& Shin, J. Y.2001. Performance of a shell-and-tube heat exchanger with spiral baffle plates. KSME international journal, 15(11): 1555-1562.

Stevanović, Ž.,Ilić, G., Radojković, N., Vukić, M., Stefanović, V., \&Vučković, G.2001. Design of shell-andtube heat exchangers by using CFD technique, Part one: Thermo-hydraulic calculation. Factauniversitatisseries: Mechanical Engineering, 1(8): 1091-1105.

Zhang, J. F., He, Y. L., \& Tao, W. Q.2009. 3D numerical simulation on shell-and-tube heat exchangers with middle-overlapped helical baffles and continuous baffles-Part I: Numerical model and results of whole heat exchanger with middle-overlapped helical baffles. International Journal of Heat and Mass Transfer, 52(23): 5371-5380.

\section{APPENDIX}

Table A. Properties of materials used in CFD analysis and Experimentation.

\begin{tabular}{|c|c|}
\hline Copper: & Steel: \\
\hline Density $\left(\rho_{\mathrm{cu})}-8978 \mathrm{Kg} / \mathrm{m}^{3}\right.$ & $\operatorname{Density}\left(\rho_{\mathrm{st})}-8030 \mathrm{Kg} / \mathrm{m}^{3}\right.$ \\
\hline Specific heat $\left(\mathrm{C}_{\mathrm{pcu}}\right)-381 \mathrm{~J} / \mathrm{kg}^{0} \mathrm{k}$ & Specific heat $\left(\mathrm{C}_{\mathrm{pst}}\right)-502.5 \mathrm{~J} / \mathrm{kg}{ }^{0} \mathrm{k}$ \\
\hline Conductivity $\left(\mathrm{k}_{\mathrm{cu}}\right)-387.6 \mathrm{~W} / \mathrm{m}^{0} \mathrm{~K}$ & Conductivity $\left(\mathrm{k}_{\mathrm{st}}\right)-16.27 \mathrm{~W} / \mathrm{m}^{0} \mathrm{~K}$ \\
\hline
\end{tabular}

Table B. Properties of hot and cold fluids used in CFD analysis and Experimentation.

\begin{tabular}{|c|c|}
\hline Water Tube side: & Water shell side: \\
\hline Density $\left(\rho_{\mathrm{t}}-996 \mathrm{Kg} / \mathrm{m}^{3}\right.$ & Density $\left(\rho_{\mathrm{s})}-990 \mathrm{Kg} / \mathrm{m}^{3}\right.$ \\
\hline Specific heat $\left(\mathrm{C}_{\mathrm{pt}}\right)-4180 \mathrm{~J} / \mathrm{kg} \mathrm{K}$ & Specific heat $\left(\mathrm{C}_{\mathrm{ps}}\right)-4180 \mathrm{~J} / \mathrm{kg} \mathrm{K}$ \\
\hline Conductivity $\left(\mathrm{k}_{\mathrm{t}}\right)-0.64 \mathrm{~W} / \mathrm{mK}$ & Conductivity $\left(\mathrm{k}_{\mathrm{s}}\right)-0.63 \mathrm{~W} / \mathrm{mK}$ \\
\hline Viscosity $\left(\mu_{\mathrm{t}}\right)-0.00079 \mathrm{Kg} / \mathrm{m}-\mathrm{s}$ & Viscosity $\left(\mu_{\mathrm{s}}\right)-0.00053 \mathrm{Kg} / \mathrm{m}-\mathrm{s}$ \\
\hline
\end{tabular}

